\title{
„CAŁY DZIEŃ ŻYJE JAKIMŚ ZDANIEM MUZYCZNYM...” MUZYKA JAKO PASJA ŻYCIA I MOTYW PRZEWODNI PISARSTWA ANNY IWASZKIEWICZOWEJ
}

W nurcie pamiętnikarskim prozy polskiej pierwszej połowy minionego stulecia trudno znaleźć diariusz w tak wielkim stopniu przeniknięty refleksją o muzyce jak Dzienniki i wspomnienia Anny Iwaszkiewiczowej ${ }^{\mathrm{I}}$. Lektura tych zapisków, pochodzących z 1. I92I-5I, daje świadectwo niezwykle szerokich horyzontów intelektualnych żony autora Stawy $i$ chwaty, przy czym dziedzina szeroko pojmowanej kultury muzycznej zajmuje tu zdecydowanie pierwszorzędne miejsce. Anna Iwaszkiewicz - wytrawna melomanka, pianistka amatorka obdarzona ponadprzeciętnymi zdolnościami do gry na fortepianie, wreszcie też wymagająca recenzentka koncertów stanowiących niejako stały kontrapunkt jej codziennego bytowania - żyła muzyką w wymiarze wręcz obsesyjnym. Jej „pamiętnik” zawiera zatem nie tylko godną podręcznikowych ujęć wykładnię indywidualnych poglądów estetyczno-muzycznych, lecz także swego rodzaju kronikę życia muzycznego Warszawy dwudziestolecia międzywojennego oraz pierwszych lat po wojnie, wzbogaconą o relacje z wydarzeń artystycznych, w których uczestniczyła podczas zagranicznych podróży. W takiej perspektywie przytoczone jako motto tytułu wyznanie można - jak się wydaje - interpretować dwojako. Z jednej strony owo „zdanie muzyczne” można odnieść bezpośrednio do nieustannego przeżywania jakiejś zasłyszanej lub zagranej na fortepianie frazy czy też

1 Tytułowy cytat pochodzi z najnowszego zbioru wszystkich opublikowanych po polsku pism Anny Iwaszkiewiczowej, zob.: Anna Iwaszkiewiczowa, Dzienniki i wspomnienia, Warszawa 2012, s. 214. Wcześniej ukazały się drukiem jedynie Dzienniki Anny Iwaszkiewicz (Warszawa 1993). 
utworu muzycznego, z drugiej natomiast do zapisanych na luźnych kartkach papieru myśli o muzyce. Nawiasem mówiąc, wszystkie dziedziny kultury przenikały się w sferze estetycznej wrażliwości autorki Dzienników i wspomnień z punktu widzenia muzyki - sztuki autonomicznej pojmowanej w kategoriach Absolutu i rzutującej tym samym na interpretację dzieł literackich, malarskich, rzeźbiarskich, architektonicznych, etc. W życiu Anny Iwaszkiewiczowej muzyka stanowiła niejako pryzmat, przez który patrzyła na całą resztę swoich intelektualno-artystycznych doznań i odkryć.

Problematyka dotycząca znaczenia muzyki w życiu autorki Dzienników i wspomnień była już przedmiotem zainteresowania badaczy. Dwie prace o charakterze przyczynkarskim opublikowała na ten temat Alicja Matracka-Kościelny². W pierwszej z nich skupiła się na szeroko pojętej muzykalności Anny Iwaszkiewiczowej, rozważanej głównie w kontekście jej metafizycznych uwarunkowań, drugą zaś poświęciła relacji tytułowej postaci z Karolem Szymanowskim jako często spotykanym członkiem rodziny (warto w tym miejscu przypomnieć, że kompozytor był kuzynem Jarosława Iwaszkiewicza) oraz twórcą wielu dzieł szczególnie bliskich jej sercu. Ponadto wzmianki o jej stosunku do twórcy Harnasiów, naznaczonego „szacunkiem i podziwem dla jego kompozycji i zalet umysłu", odnajdujemy w zwięzłym studium Doroty Chłandy i Małgorzaty Zawadzkiej³. Niniejszy artykuł stanowi próbę rozwinięcia zarysowanych przez wszystkie wymienione autorki wątków oraz uzupełnienia ich o nowe treści zaczerpnięte z pism literackich Anny Iwaszkiewiczowej, tj. z dzienników, tekstów okolicznościowych i listów.

Anna Iwaszkiewicz urodziła się I7 XII I897 r. w Brwinowie. Dorastała w rodzinie, w której pielęgnowano zamiłowanie do muzyki. Była jedynym dzieckiem Stanisława Wilhelma Lilpopa - zamożnego warszawskiego przemysłowca i właściciela dóbr ziemskich - oraz Jadwigi ze Stankiewiczów. Gdy miała zaledwie dwa lata, „wyrodna” matka porzuciła rodzinę, wiążąc się na stałe w wybitnym pianistą Józefem Śliwińskim. Warto nadmienić, że wirtuoz ten cieszył się wówczas szczególnym uznaniem i popularnością; stawiano go w jednym rzędzie obok takich mistrzów sztuki pianistycznej jak Józef Hofmann czy Sergiusz Rachmaninow4.

Wychowaniem, a następnie też edukacją Hani - bo tak była ona przez całe życie nazywana w gronie rodziny i najbliższych przyjaciół - zajęła się ciotka, tj. siostra ojca, Aniela Pilawitzowa. Decydowała o dziecięcych i młodzieńczych losach swojej bratanicy, w czym pomagał jej znacznie starszy mąż Henryk. On to właśnie - z zawodu

2 Alicja Matracka-Kościelny, „Muzyka w życiu i twórczości Anny Iwaszkiewiczowej”, w: Anna Iwaszkiewiczowa. W setna rocznicę urodzin, Podkowa Leśna 1997 (= Stawisko. Almanach Iwaszkiewiczowski 3), s. 115-125, oraz tejże: „Anna Iwaszkiewiczowa - Karol Szymanowski”, Polski Rocznik Muzykologiczny 18 (2020), s. 225-235.

3 Dorota Chłanda, Małgorzata Zawadzka, „O Szymanowskim z troską. Listy Anny i Jarosława Iwaszkiewiczów i Hélène Kahn-Caselli”, Polski Rocznik Muzykologiczny 18 (2020), s. 236-254.

4 Zob.: Radosław Romaniuk, „Anna od aniołów. O Annie Iwaszkiewiczowej”, w: tegoż, One. Kobiety, które kochaty pisarzy, Warszawa 2014, s. 69. 
bankier uchodzący za człowieka wszechstronnie wykształconego - zaskarbił sobie dozgonną wdzięczność „przybranej córki”. Jak można bowiem na ten temat przeczytać w źródłach, „Hania całe życie twierdziła, że wiele mu zawdzięcza. Polecał jej właściwe lektury i dbał o jej rozwój intelektualny”s. Muzykalność natomiast panna Lilpopówna odziedziczyła - jak się wydaje - przede wszystkim po ojcu. Świadczyć o tym mogą następujące słowa zapisane w pamiętniku jej matki Anieli Lilpop, secundo voto Śliwińskiej:

Mówiłam nieraz, że nie mogłabym pójść za mąż za człowieka, który muzyki nie czuł i nie lubił. Ten, który miał zostać moim mężem, pociągnął mnie do siebie dwoma rzeczami: pięknym tembrem głosu i ogólną artystyczną ogładą, i wielką naprawdę muzykalnością. Jemu zawdzięczam rozwinięcie mojej muzykalności. Nie było koncertu ani przedstawienia w operze, na którym byśmy nie byli. A najlepsze wrażenia moje z pożycia z nim były, gdy w przypływie dobrego humoru wyśpiewywał - i to z bajeczną czystością i precyzją - całe opery ${ }^{6}$.

Przyszła żona Jarosława Iwaszkiewicza długo musiała oczekiwać na właściwą ocenę swojej wysokiej kultury intelektualnej i artystycznej. W młodym wieku nigdy bowiem nie uczęszczała do żadnej szkoły. Jej ojciec, w porozumieniu z nieco dalszą rodziną, zdecydował się bowiem na wychowanie i kształcenie córki w domowych warunkach, w wyniku czego Hania do uzyskania pełnoletności pozostawała pod nieustającą opieką bon i guwernantek. Jedna z nich - bliżej dziś nieznana panna Florentyna Maillot - okazała się szczególnie wymagającą mentorką, a lektorką języka francuskiego; jako jedyna zresztą zapisała się w annałach historii rodu Iwaszkiewiczów. Na stronach opublikowanych wspomnień prawnuczki Anny i Jarosława można bowiem odnaleźć następujące stwierdzenie: „Jarosław Iwaszkiewicz, gdy jego żona robiła coś wyjątkowo szalonego bądź niekonwencjonalnego, żartował: «Oj, panna Maillot byłaby niezadowolona»"7.

Paradoksalny może wydawać się fakt, iż Hania Lilpopówna, pozbawiona formalnej (tj. instytucjonalnej) edukacji, wyrosła na osobę o szerokich horyzontach intelektualnych, popartych dużą erudycją oraz wielką wrażliwością na wszelkie dziedziny sztuki, z muzyką na pierwszym planie. O jej rozwoju duchowym zadecydował w dużym stopniu ponad trzyletni pobyt w Rosji - najpierw w Kijowie, a wkrótce potem w Moskwie - podczas I wojny światowej. Na potwierdzenie tak silnych doznań osobistych dwudziestoletniej kobiety można przywołać następujące jej słowa:

Najukochańsze, nad wszystko drogie, z niczym niezrównane wspomnienia moskiewskie. [...] Kocham te czasy nie tylko dlatego, że były najpiękniejszą fazą mojego życia, obudzeniem się do wszystkiego, czym jedynie żyć warto... ${ }^{8}$.

5 Ludwika Włodek, Pra. Iwaszkiewiczowie. Opowieść o rodzinie, Kraków 2012, s. 78.

6 Ibid., s. 102-103.

7 Ibid., s. 80 .

8 Ibid., s. 81. 
Pierwszą wielką fascynacją muzyczną Anny Iwaszkiewiczowej okazał się Skriabin. Jego Poemat ekstazy, który usłyszała po raz pierwszy w Moskwie w roku 1917, był dla niej - jak sama wyznała - prawdziwym objawieniem sztuki doświadczanej przede wszystkim w wymiarze mistyczno-religijnym i zawładnął jej artystyczną wrażliwością na całe życie. Przez pryzmat tego dzieła czytała, pisała a także słuchała muzyki, odbierając niejako synestetycznie utwory literackie, jak szczególnie bliską jej prozę Marcela Prousta i poezję Juliusza Słowackiego (w tym przede wszystkim poemat Król-Duch), oraz przenikniętą mistyczną aurą III Symfonię Karola Szymanowskiego. Jako świadectwo tego rodzaju skojarzeń można przytoczyć następujący fragment listu napisanego do męża w październiku I924 r. z Zakopanego, gdzie wówczas gościła u zaprzyjaźnionej rodziny Mieczysława i Heleny Rytardów:

To, że Miecio [Rytard] tak jak ja rozumie Skriabina, było zupełnie nieoczekiwanym; zgodziliśmy się zupełnie na to, że Ekstaza to Król-Duch w muzyce. Tam też są te krwawe pożary i walki ducha, a potem to, co zapowiedziane w ostatniej strofie pierwszego rapsodu: Morza się cofną - góry pójdą pyłem - I świat się komet deszczami zatrwoży - Gdy duchem spełnię co ciałem spełniłem. Duch ukazany w pierwszej świata zorzy... Któremu Pan Bóg swych zasłon uchyla - a lat tysiące są jak jedna chwila9.

Zacytowane wersy wieszcza pozwalają domniemywać, że Annie Iwaszkiewiczowej znany był już wówczas także projekt Skriabinowskiego Misterium, bowiem literackie pokrewieństwo z tekstem do L’Acte préalable wydaje się w tym przypadku bardzo prawdopodobne.

W kwestii „synestetycznego” przeżywania muzyki samej w sobie, w odniesieniu do czwartego dzieła symfonicznego Skriabina, warto wskazać na jeszcze jedną analogię - dotyczącą Pieśni o nocy, tj. III Symfonii Szymanowskiego. W następującym cytacie, który notabene pozwala uznać Annę Iwaszkiewicz za prekursorkę badań nad tzw. ekspresjonizmem słowiańskim w muzyce pierwszej dekady XX w., odnajdujemy nie tylko wyraz uczuć przesiąkniętej prawdziwą pasją melomanki, lecz także swego rodzaju świadectwo ambicji słuchaczki pretendującej do roli profesjonalnego krytyka muzycznego. Na kartach jej dziennika z lutego 1926 r. czytamy:

Parę dni temu po raz drugi, po dwóch latach słyszałam III Symfonię Karola. Genialność tego dzieła jest z gatunku tych, które jak piorun uderzają w nas od pierwszego razu. [...] Doznałam tego samego zachwytu, tej samej rozkoszy co za pierwszym razem, tej samej ekstazy, jak podczas Ekstazy Skriabina, z którą według mnie symfonia Karola ma dużo wspólnego. Moment, kiedy pierwszy raz odzywa się głos, a potem kiedy ginie w orkiestrze, która wybucha jakąś olbrzymią falą, jest najgenialniejszą rzeczą, jaką Karol napisał, i pewna jestem, że to właśnie jest szczytem jego twórczości, jak Ekstaza w twórczości Skriabina ${ }^{\mathrm{IO}}$.

9 Anna i Jarostaw Iwaszkiewiczowie, Listy 1922-1926, Warszawa 1998, s. 175. Zob. także: Juliusz Słowacki, Wiersze i poematy. Wybór, Warszawa 1976, s. 423.

10 A. Iwaszkiewiczowa, Dzienniki i wspomnienia, s. 119-120. 
Znamienne, że o żadnym z późniejszych utworów Szymanowskiego, z którym pozostawała w przyjacielskich stosunkach do końca jego życia, nie wypowiedziała się $\mathrm{w}$ podobnie entuzjastycznym tonie.

Muzyczno-literackie parantele, jakich jest wiele w Dziennikach i wspomnieniach, wiązały się przede wszystkim - jak wspomniano - z lekturą powieści Prousta. Warto dodać, że Anna Iwaszkiewiczowa była też autorką przekładu obszernych fragmentów siedmiotomowego dzieła francuskiego pisarza pt. W poszukiwaniu straconego czasu. W kontekście swojej fascynacji tą prozą przywołała ona jedną z miniatur Skriabina i zarazem jedyny poza Poematem ekstazy utwór rosyjskiego kompozytora wymieniony w jej pamiętniku. W marcu I923 r. zanotowała:

Teraz właśnie przeczytałam pierwszy tom Prousta. Są tam rzeczy świetne. Całe przeżycie muzyczne nadzwyczajne. Zresztą miałam identycznie to samo z etiudą op. I Skriabina, ale z zapartym wprost oddechem czytałam to miejsce, gdzie on pisze o wrażeniach, których doznaje na widok pewnych rzeczy... ${ }^{\text {II }}$.

W świetle tych słów można sądzić, iż wielbicielka muzyki twórcy Vers la flamme miała ten sam dar, który dany był kompozytorowi, czyli synestetyczną wrażliwość na sztukę, wynikającą z kojarzenia dźwięków, słów i obrazów ${ }^{\mathrm{I2}}$.

Po powrocie z Moskwy do Polski w roku I9ı8 Hania Lilpopówna stała się propagatorką muzyki Skriabina w Polsce. Jej pierwszym krokiem w tym kierunku było „kameralne” prawykonanie Ekstazy, które pozostało bez echa w ówczesnej prasie warszawskiej; stąd też nie sposób ustalić jego daty. Jedyne świadectwo tego wydarzenia odnajdujemy we wspomnieniach zaprzyjaźnionego z rodziną Lilpopów pianisty Romana Jasińskiego, który w wywiadzie udzielonym Robertowi Jarockiemu, zamieszczonym na łamach miesięcznika Literatura, stwierdził między innymi:

A już koniecznie trzeba wspomnieć, że Hani zawdzięczałem poznanie muzyki Skriabina, którą ona wcześniej „odkryła” w Rosji. Wróciła z Moskwy, gdzie panował szczególny kult Skriabina. W Warszawie wtedy nie miano pojęcia o tej muzyce. Pamiętam, że zorganizowała w sali firmy Herman i Grossman przy ulicy Mazowieckiej zamknięty koncert, gdzie wykonywała wtedy z zaprzyjaźnioną pianistką, której nazwiska nie pamiętam, na dwa fortepiany Poemat Ekstazy Skriabina. Naturalnie, ten utwór wymagał orkiestry, żeby wydobyć z niego wszystkie barwy i możliwości. Dwa fortepiany dawały bardzo ograniczone wyobrażenie o tym dziele, ale Lilpopównie zawdzięcza zaproszone grono uczestników koncertu, czy też lepiej powiedzieć audycji, pierwsze zetknięcie się ze Skriabinem ${ }^{13}$.

11 Ibid., s. 96.

12 Kwestia synestezji Skriabina nadal pozostaje kontrowersyjnym problemem dla badaczy jego twórczości. Za przyjęciem tej hipotezy jako właściwej przemawiają świadectwa co najmniej dwóch znajomych kompozytora, tj. Charlesa Myersa i Leonida Sabaniejewa, zob. na ten temat: Tomasz Baranowski, Profile Skriabina. Szkice z poetyki twórczości, Białystok 2013, s. 102-104.

13 „Z Albumu Romana Jasińskiego. O Lilpopach, Hannie i Jarosławie Iwaszkiewiczach i trochę o samym właścicielu albumu" [wywiad prasowy udzielony przez Romana Jasińskiego Robertowi Jarockiemu], Literatura 14 (1985) nr 5, s. 7. Por. także: T. Baranowski, Profile Skriabina, s. 181. 
Obok Skriabina kompozytorem, którego nazwisko najczęściej występuje w diariuszu Anny Iwaszkiewiczowej, jest Fryderyk Chopin. To jego muzyką „karmiła się” na co dzień jako słuchaczka niezliczonych koncertów i recitali chopinowskich (odbywających się również w zaciszu domowego salonu muzycznego Iwaszkiewiczów), a także włączając wiele jego utworów do własnego repertuaru pianistki amatorki. Ponadto w roku 1927 przeczytała najnowsze wydanie dwutomowej biografii kompozytora autorstwa Ferdynanda Hoesicka, nie kryjąc przy tym rozczarowania lekturą tego studium. Zanotowała na ten temat następującą krytyczną opinię: „Czytam teraz ogromne dzieło Hoesicka o Chopinie. Styl nieprawdopodobnie naiwny, wprost śmieszny, gadulstwo nieznośne [...]"I4. O ile jednak w odniesieniu do Skriabina jej wspomnienia dotyczyły niemal wyłącznie Ekstazy przywoływanej jako „objawienie” w wymiarze duchowym, o tyle w przypadku Chopina mamy do czynienia z pogłębioną refleksją o charakterze estetyczno-muzycznym, zawierającą sądy o charakterze wartościującym. Anna Iwaszkiewiczowa szczególnie ceniła sobie mazurki, etiudy, sonaty, „perwersyjną" - jak pisała - Barkarolę oraz Poloneza-fantazje, mniejszym zaś uznaniem darzyła koncerty, których wykonań wielokrotnie słuchała; zwłaszcza podczas finału II Międzynarodowego Konkursu Chopinowskiego w Warszawie w marcu 1932 roku. W swoim dzienniku napisała na ten temat:

Jedynie koncert e-moll w czasie finałów (22, 23 marca) zmęczył mnie, ale to zresztą nie dziwi mnie, bo mówiąc Chopin, nie myślę nigdy o koncertach, uroczych, ale tak bardzo jeszcze młodzieńczych i, powiedziawszy szczerze, tak słabych jako ensamble, jako kompozycja. Sonaty, fantazje, etiudy, mazurki za to wydają mi się coraz genialniejsze, zawrotnie doskonałe, szczyty formy ${ }^{15}$.

Głębi i genialności muzyki Chopina, tj. wzruszeń, jakich Anna Iwaszkiewicz doznawała podczas koncertów wybitnych i często zaprzyjaźnionych z nią - o czym jeszcze będzie mowa - pianistów wirtuozów, towarzyszy bardzo osobista refleksja nad losem kompozytora i jego twórczości. Zdawała ona sobie sprawę z faktu, iż muzyka twórcy Poloneza-fantazji dalece przewyższała estetyczno-muzyczne horyzonty melomanów z I poł. XIX stulecia, dla których Chopin był przede wszystkim pianista, arystokratą z krwi i kości, oraz - co za tym idzie - osobą mile widzianą na salonach Paryża. W roku I93I autorka dzienników wypowiedziała bowiem następujący pogląd, z którym to notabene w pełni zgadzał się Karol Szymanowski:

Karol mówił to samo, co zawsze myślę o Chopinie, że całe jego powodzenie za życia było tylko powodzeniem jego osobistym jako czarującego człowieka i niezwykłego pianisty. Muzyka jego, a przynajmniej to, co w niej jest najlepsze, nie mogło być doceniane przez współczesnych ${ }^{16}$.

14 A. Iwaszkiewiczowa, Dzienniki i wspomnienia, s. 163.

15 Ibid., s. 241.

16 Ibid., s. 237. 
Niemal dwadzieścia lat później potwierdziła swój osąd na ten temat, podejmując niejako dyskusję z nieżyjącym już kuzynem swego męża. Zanotowała wówczas:

[...] Karol niegdyś powiedział u nas, przegrywając mazurki: Nigdy nie uwierzę, żeby sto lat temu komuś się to naprawdę podobało. Myślałam o tym, że niektóre mazurki Chopina są w stosunku do swojej epoki o wiele bardziej rewolucyjne niż mazurki Karola. One jeszcze teraz są „dziwne” ${ }^{17}$.

W świetle przytoczonych słów, z jednej strony można zastanawiać się nad fenomenem tzw. mazurkomanii jako potwierdzonego w źródłach jednego z „efektów Chopina” w II poł. XIX w., z drugiej natomiast - co w tym przypadku wydaje się istotniejsze - nad kwestią jakże dogłębnej znajomości twórczości Chopina, wyrażonej na kartach pamiętnika Anny.

Warto dodać, że doświadczanie muzyki Chopina było w tym przypadku ściśle powiązane ze znajomością biografii kompozytora oraz płynących z niej wzruszeń; niekiedy - jak to w dzienniku zazwyczaj bywa - bardzo osobistej natury. W lipcu I927 r. Anna Iwaszkiewiczowa zanotowała:

Czytałam cioci La vie de Chopin Pourtalèsa. Listy Chopina czytałam po polsku z Hoesicka, również i śmierć, te ostatnie dnie tam tak szczegółowo opisane. Tak niesłychanie zawsze wzrusza mnie to życie i ten niesłychany smutek, ten tragizm ostatniej samotności; listy z Anglii: „a sztuka moja gdzie mi się podziała, a serce moje gdziem zaprzepaścił...”⒏

W panteonie wielkich kompozytorów, których muzykę Anna Iwaszkiewicz ceniła najwyżej, pierwsze miejsce zajmuje Jan Sebastian Bach. Zachwyt nad muzyką Bacha wyrażał także jej mąż Jarosław. Dowodem tego może być na przykład jego relacja z koncertu w Paryżu, przekazana w liście do żony, datowanym na 5 III 1926 r.; pisał w nim między innymi: „[...] cudo zupełne, II Koncert brandenburski Bacha, na skrzypce, flet, obój i trąbkę - coś niesamowitego, jaki piękny, wyliśmy z zachwytu, jak cała sala”'

Jakkolwiek Anna Iwaszkiewiczowa porównywała w swych refleksjach, a także $\mathrm{w}$ doświadczeniach $\mathrm{w}$ grze na fortepianie, Bacha z Chopinem, to jednak nie ulega wątpliwości, iż to muzyka twórcy zwanego niekiedy w muzykografii mianem piątego ewangelisty, stała w jej artystyczno-muzycznym „rankingu” zdecydowanie na pierwszym miejscu. Do Chopina było wszak w tej konkurencji niedaleko; wskazuje na to na przykład następujące porównanie obydwu kompozytorów, dokonane w odniesieniu do wspomnianego Konkursu Chopinowskiego: „[...] oprócz Bacha żaden kompozytor "nie wytrzymałby» takiego odbębniania przez trzy tygodnie po parę godzin dziennie i to ciągle tych samych rzeczy”. Jednakże niedługo potem - w czasie krótkotrwałej podróży po Niemczech - nazwała lipskiego kantora „największym

17 Ibid., s. 422 .

18 Ibid., s. 183-184.

19 Anna i Jarostaw Iwaszkiewiczowie. Listy, s. 469. 
z największych geniuszy" ${ }^{20}$. W muzyce Bacha znajdowała przede wszystkim chwile ukojenia „tęsknoty metafizycznej”, któremu na przeszkodzie często stawał „kołowrót domowy” ". Preludia i fugi z Das wohltemperierte Klavier - ów „stary testament każdego pianisty" (aby przywołać znaną metaforę Hansa von Bülowa)22 - grywała niemal codziennie na fortepianie w ramach domowego muzykowania. Największe wrażenie wywarła na niej jednak Msza h-moll, opus magnum kompozytora, którą usłyszała przez radio z brukselskiej rozgłośni podczas kilkudniowej gościny w domu Marii i Jerzego Andrzejewskich w Szczecinie w lutym 1949 roku. Na kartach dzienników odnajdujemy następujące świadectwo tego doznania:

Udało nam się złapać wspaniałe wykonanie Mszy h-moll Bacha z Zurychu. Pierwszy raz słyszałam ten genialny utwór w całości i byłam zupełnie oszołomiona, zupełnie submergée tym nawałem muzyki, tą potęgą, tą niewyobrażalną doskonałością, wobec której człowiek zostaje absolutnie bez słów, bez możności wyrażenia tego, co czuje, co o tym myśli po prostu²3.

Wiele wskazuje na to, że Anna Iwaszkieczowa w ogóle bardzo ceniła muzykę twórców o germańskim rodowodzie. Na kartach dzienników wyznała na ten temat między innymi: „Ach, jak lubię Niemcy! O ileż bliżsi mi są ich wielcy ludzie, zwłaszcza ich muzycy, niż ci, którymi szczyci się Francja”"24. Owo uwielbienie dla kultury niemieckiej datuje się na lata poprzedzające wybuch II wojny światowej; później bolesne doświadczenie nazistowskich zbrodni zweryfikowało tę entuzjastyczną postawę.

Szczególnym zainteresowaniem żona Jarosława darzyła twórczość Ryszarda Wagnera, którego partytury - w formie wyciągu fortepianowego - „przegrywała” wielokrotnie; samotnie lub na cztery ręce ze spowinowaconym z nią Karolem Szymanowskim. Z wielkimi dziełami twórcy Pierścienia Nibelunga miała okazję zapoznać się w swoich młodych latach. „Cudowne przedstawienie” Tristana i Izoldy obejrzała podczas kilkudniowego pobytu w Berlinie w kwietniu 1923 r., kilka lat później zaś donosiła o „wspaniałej” premierze Parsifala w Operze Warszawskiej, która odbyła się w marcu I927 r. pod dyrekcją Emila Młynarskiego ${ }^{25}$. Szczególnie bliski był jej jednakże Wagnerowski Zygfryd, którego wyciąg fortepianowy często „czytała” na fortepianie jako kołysankę dla swojej pierwszej córki Marii. Przy okazji tych osobistych wspomnień podzieliła się także estetyczno-muzyczną refleksją nad tym dziełem:

Muzyka właśnie tu oddaje to, co słowami tylko z grubsza mogłoby być powiedziane: tajemniczą zapowiedź szumu lasu. W tej tajemniczej harmonii zawiera się istotnie coś - to uczucie, które tak często mamy, kiedy jesteśmy sami wobec przyrody ${ }^{26}$.

20 A. Iwaszkiewiczowa, Dzienniki i wspomnienia, s. 241 i 252.

21 Zob.: ibid., s. 227.

22 Zob.: Martin Else, Meilensteine der Bach-Interpretation 1750-2000, Berlin-Heidelberg 2000, s. 362.

23 A. Iwaszkiewiczowa, Dzienniki i wspomnienia, s. 416.

24 Ibid., s. 252.

25 Zob.: ibid., s. 25 i 166.

26 Ibid., s. 273. Zapewne jest tu mowa o fragmencie z II aktu Wagnerowskiego Zygfryda, zwanego popularnie „Szumem lasu”. 
W repertuarze Anny Iwaszkiewiczowej-pianistki ważną pozycję stanowiła wreszcie muzyka Beethovena. Zwłaszcza kwartety twórcy Fidelia grywała często - z reguły na cztery ręce lub na dwa fortepiany z Karolem Szymanowskim. Szczególnym uwielbieniem darzyła Koncert skrzypcowy Beethovena, który uznała za „jedno z najczystszych arcydzieł formy" ${ }^{27}$. Porównała przy tym ten utwór z I Koncertem skrzypcowym Szymanowskiego w swojej osobistej „recenzji” koncertu z udziałem światowej sławy skrzypka Bronisława Hubermana, którego słuchała w warszawskiej Filharmonii Narodowej I7 IV 1929 roku. Na kartach Dzienników odnajdujemy bowiem następujący osąd: „Koncert Beethovena i koncert Karola, dwa najpiękniejsze na świecie” ${ }^{28}$. Sonat Beethovena, czyli - powracając do metafory Hansa von Bülowa - „nowego testamentu każdego pianisty” ${ }^{29}$, jednak raczej nie „odkrywała” przy fortepianie; w jej zapiskach nie ma bowiem wzmianek na ten temat.

Uwielbienie okazywane wobec muzyki Bacha, Beethovena i Wagnera, a także wyrażony podczas zagranicznej podróży w sierpniu I932 r. - zachwyt nad pejzażem Niemiec, kraju odkrywanego wówczas jako „la terre glorieuse” ${ }^{\circ 0}$, wydają się stanowić „dominantę” artystycznych upodobań Anny Iwaszkiewicz. Skojarzenia te nie pozostawiają cienia wątpliwości, iż w sferze jej doznań estetycznych kultura muzyczna Niemców zajmowała poczesne miejsce. Zdecydowanie mniej wyrozumiała była ona w stosunku do muzyki francuskiej. O muzyce francuskich impresjonistów wypowiadała się w tonie raczej negatywnym. Słów krytyki nie szczędziła przede wszystkim Debussy’emu, o którego muzyce, sprzeciwiając się nieśmiało opinii Karola Szymanowskiego, napisała między innymi:

Oczywiście, nie mogę mieć tak dalece zdania w tej kwestii, ale osobiście dla mnie to, co Debussy daje, jest tak czcze, tak powierzchowne przy całej swojej błyskotliwości i pomimo tego pewnego uroku, jaki jego muzyka posiadła w wysokim stopniu, że nie można z tego czerpać jak z nieprzebranego źródła. Przede wszystkim jest tam ostatecznie wielka monotonia, powtarza się szalenie i przez to bardzo prędko nuży ${ }^{31}$.

Nieco łagodniejszy osąd Anna Iwaszkiewicz sformułowała w odniesieniu do twórczości Ravela, notując dalej:

A Ravel? Uroczy także, czasem dający dziwne wiosenne jakby wzruszenia, ale to także jeszcze nie to, co „żyć będzie poprzez wieki”. Mam wrażenie, że ta cała szkoła ma dla nas taki czar, bo jest reakcją przeciw ciężkiej symfonicznej muzyce powagnerowskiej, upaja nas jak czyste i chłodne powietrze górskie ${ }^{32}$.

27 Zob.: ibid., s. 247.

28 Ibid., s. 211.

29 Zob.: M. Else, Meilensteine, s. 364.

30 Zob.: ibid., s. 252.

31 A. Iwaszkiewiczowa, Dzienniki i wspomnienia, s. 65.

32 Ibid. 
O nowszej muzyce, tj. tej, w której zamanifestowało się ostateczne zerwanie z systemem tonalności funkcyjnej dur-moll, na kartach Dzienników i wspomnień, nie ma już właściwie mowy. Wyjątek stanowi oczywiście Poemat ekstazy Skriabina - pojmowany jako swoista idée fixe autorki, a także twórczość Karola Szymanowskiego, z którym była ona szczególnie związana w codziennym życiu; poprzez relacje rodzinne oraz - w konsekwencji - liczne grono wspólnych przyjaciół i znajomych. Wątki powiązań Anny Iwaszkiewiczowej z twórcą Harnasiów zostały już - jak wspomniano - dokładnie przebadane przez Alicję Matracką-Kościelny. Warto w tym miejscu jedynie przypomnieć fakt, iż to właśnie żona kuzyna kompozytora była pośrednią inspiratorką powstania jego ostatniego utworu o tematyce sakralnej, a mianowicie Litanii do Marii Panny. Dzieło to napisał Szymanowski na kanwie wiersza Jerzego Lieberta, przedwcześnie zmarłego poety z grupy Skamander. Ten religijny liryk poznał on bowiem właśnie dzięki Annie Iwaszkiewiczowej, której owa siedmiozwrotkowa litania, inkrustowana później muzyką, została zadedykowana ${ }^{33}$.

Dzienniki i wspomnienia zawierają nie tylko bardzo subiektywne ujęcie poglądów estetyczno-muzycznych autorki, lecz także swego rodzaju kronikę życia muzycznego tamtej epoki. Jako słuchaczka całego mnóstwa koncertów i przedstawień operowych doskonale sprostała ona roli recenzentki wielu artystycznych wydarzeń, skrupulatnie śledząc i oceniając występy licznych znanych w owym czasie muzyków. Wielu z nich znała na co dzień, dzięki koneksjom o charakterze rodzinno-przyjacielskim. Wymienić tu należy przede wszystkim takie nazwiska, jak Paweł Kochański, Artur Rubinstein, Raul Koczalski czy Zbigniew Drzewiecki; z ich grą stykała się wyjątkowo często, także w zaciszu domowym. Miała ponadto okazję podziwiać wirtuozerię rzadko goszczących wówczas w Warszawie wybitnych artystów z zagranicy, tj. na przykład hiszpańskiego wiolonczelisty Gaspara Cassadò, którego występ w Warszawie w październiku I928 r. ostatecznie zaważył na jej wrażeniu z koncertu. Zanotowała wówczas bowiem między innymi: „W filharmonii zawsze te same półpustki, te same ciemności, te same twarze i nudy. Koncert nienadzwyczajny, chociaż gra Cassady świetna" 34 .

W swoich opiniach na temat sztuki wykonawczej muzyków - głównie pianistów, którzy byli jej najbliżsi - Anna Iwaszkiewicz brała przede wszystkim pod uwagę głębię interpretacji, na drugim planie stawiała natomiast kwestie natury techniczno-wykonawczej. Jednak także i w tej drugorzędnej materii potrafiła wyrażać krytyczne oceny. Jedna z nich - utrwalona na kartach pamiętnika - dotyczy Ignacego Jana Paderewskiego, którego po raz pierwszy i zarazem jedyny usłyszała „na żywo” w Paryżu w czerwcu 1932 r., podczas uroczystego koncertu zorganizowanego z okazji setnej

33 Zob.: Zofia Helman, Między romantyzmem a Nowq Muzykq. Warszawa 2013 (= Historia muzyki polskiej 6), s. 455.

34 A. Iwaszkiewiczowa, Dzienniki i wspomnienia, s. 204. 
rocznicy przybycia Fryderyka Chopina do Francji. W następującej jej wypowiedzi odnajdujemy bowiem śmiałą próbę podważenia mitu tego wielkiego artysty i męża stanu jako wirtuoza gry na fortepianie:

Jednak nieprawdopodobna kariera, którą zrobił, jest czymś zastanawiającym. Nie ma chyba na świecie drugiego człowieka, który mógłby pochwalić się tym, że koronowana głowa wstaje, jak on wchodzi na salę [...]. Wracając jeszcze do jego gry, to dziwię się, że nikt nie zwraca uwagi na rzeczy, które u kogo innego uważałoby się za wprost horrendalne i niedopuszczalne; na przykład stale lewa ręka na jedną czwartą sekundy przed prawą, jakiś okropny, sentymentalny, w najgorszym gatunku staropanieński efekt, albo dodanie jednej nuty o oktawę niżej w zakończeniu larga sonaty $h$-moll, po tych dwóch akordach tak idealnie doskonałych ${ }^{35}$.

Niejako na osłodę tej druzgocącej „recenzji” jej autorka dodała: „[...] według mnie grał bardzo pięknie tylko walce i mazurki, choć może trochę za wolno. Scherzo świetne" ${ }^{36}$.

Również w znacznie późniejszych, tj. już powojennych relacjach Anna Iwaszkiewiczowa - jako „kronikarka” polskiego życia muzycznego - pozostawiła wiele cennych refleksji na temat artystów młodszego pokolenia. Z właściwą jej emocjonalno-religijną wrażliwością na muzykę wypowiedziała się po recitalu Jana Ekiera, który odbył się 3I X 1947 r., niedługo po obchodach 98. rocznicy śmierci Chopina, uczczonych uroczystym koncertem w Filharmonii Warszawskiej. Zanotowała wówczas:

Wczorajszy koncert Ekiera wywarł na mnie tak głębokie wrażenie, że nie przestaję o nim myśleć, a raczej jakby „nim żyć”, i chciałabym coś o tym napisać, ale o muzyce pisać jest tak trudno; można tylko fachowo, ale przecież nie to ja czuję w sobie. Zastanawia mnie zawsze jednak fakt, jak to jest, jak z rzeczą, którą opisać można tylko ścisłymi kategoriami. Powstają wrażenia i przeżycia najgłębsze, najbardziej niemożliwe do opisania słowami, przeżycia najbardziej zbliżone do przeżyć religijnych ${ }^{37}$.

Ceniła sobie także młode talenty, którym niekiedy niejako przewidziała przyszłą wielką karierę. Dużym uznaniem darzyła sztukę dyrygencką Stanisława Wisłockiego, wspominając w zapiskach z dnia $2 \mathrm{~V} 1949$ r. prowadzony przez niego koncert w Filharmonii Warszawskiej, wypełniony wyłącznie muzyką Bacha; wtedy właśnie zanotowała słowa w najwyższym stopniu świadczące o jej szczególnym stosunku do twórczości lipskiego kantora, a mianowicie: „Myśl o geniuszu Bacha czasami wprost przeraża mnie. Tak, zdaje się, że Huxley miał rację, uważając ją za wystarczający dowód istnienia Boga" ${ }^{38}$.

W podobnie pochwalnym tonie Anna Iwaszkiewicz wypowiedziała się na temat pianistyki Kazimierza Serockiego, którego poznała latem w Ustce w 1949 roku. Warto przytoczyć jej obszerną relację z prywatnej audycji dla przyjaciół w pensjonacie

35 Ibid., s. 254.

36 Ibid.

37 Ibid., s. 351-352.

38 Ibid., s. 425. 
ZAiKS-u, ponieważ przebija z niej nie tylko indywidualna ocena interpretacji, lecz także dogłębna znajomość jednego z ulubionych przez nią dzieł Chopina. W eseju zatytułowanym Moje „Fontainebleau”, zawierającym wspomnienia z tych nadmorskich wakacji, odbywanych regularnie na przełomie lat czterdziestych i pięćdziesiątych minionego stulecia, napisała:

[...] największą „atrakcją” tego pobytu był Serocki, o którym jeszcze nikt nie wiedział, że komponuje, a mówiono o nim tylko, że to młody, bardzo zdolny pianista, uczeń Szpinalskiego. Ćwiczył wtedy Sonatę b-moll i rano nigdy nie mogłam się zdecydować wyjść na plażę, kiedy z saloniku mimo zamkniętych drzwi zaczynały dolatywać mnie urzekające dźwięki fortepianu. [...] Kiedyś wieczorem urządził audycję specjalnie dla Kępińskich i dla mnie, grając nam już całą sonatę. Grał ją naprawdę bardzo pięknie i choć uważam go za bardzo zdolnego kompozytora, jednak żałuję, że tak zarzucił pianistykę. Szczególnie pierwsza część, która, moim zdaniem, jest jednym z tych nieprześcignionych szczytów geniuszu Chopina, brzmiała w jego wykonaniu właśnie tak, jak wyobrażam sobie, że brzmieć powinna. Najpierw te kilka nut, dziwna, ponura fraza, którą nazywam zawsze „zejściem do Hadesu”, i zaraz po tym burzliwy, gwałtowny, jakby zdyszany, haletant pierwszy temat, ale zwłaszcza finał tej części szarpiący, wściekły, uparcie dobijający się czegoś w jakimś rozpaczliwym krzyku i urwany potem nagle, oddany był zawsze przez niego z wewnętrzną pasją, z najgłębszym zrozumieniem niesamowitej genialności tego utworu ${ }^{39}$.

Lista nazwisk wybitnych muzyków - kompozytorów, dyrygentów i solistów wymienionych na kartach Dzienników i wspomnień zawiera wiele innych postaci, dla których zabrakło miejsca w niniejszym szkicu. Anna Iwaszkiewiczowa w pełni wykorzystała dar wyjątkowej, emocjonalnej i niekiedy wręcz mistycznej wrażliwości na sztukę, przy czym - jak wyznała - „ciągle żyła muzyką” ${ }^{\circ}$; sztuka dźwięków stanowiła w tym przypadku bodaj jedyną pewną „odskocznię” od przypadającej na trudne czasy polskiej historii codzienności. Jej refleksje, utrwalone w pamiętnikarskich zapiskach, jawią się poza tym jako cenne źródło do badań nad polską kulturą muzyczną ponad trzech dekad I poł. XX wieku. Stanowią one ponadto istotny przyczynek do wyczerpującej monografii tej wybitnej postaci, która wciąż czeka na swojego autora. Cennym punktem wyjścia do tego rodzaju studium może być przywołany na wstępie esej Radosława Romaniuka ${ }^{4}$.

Wart rozwinięcia wydaje się wreszcie wątek wzajemnych inspiracji Anny i Jarosława Iwaszkiewiczów w sferze rozwijania muzycznych pasji i kształtowania upodobań estetycznych. Małżonkowie bowiem w wielkim stopniu dzielili się ze sobą doznaniami i refleksjami płynącymi z obcowania z muzyką. Świadczyć o tym mogą m.in. ich wspólne, dalekie podróże, których głównym, jeśli nie jedynym celem był udział w wydarzeniach muzycznych. Należy wspomnieć tu na przykład wyjazd na festiwal wagnerowski do Bayreuth w lipcu I93I r., czy też uczestnictwo w trzydniowym

39 Ibid., s. 473.

40 Zob.: ibid., s. 214.

41 Zob. przyp. 4. 
Festiwalu Muzyki Polskiej w Paryżu, zorganizowanym w I932 r. dla upamiętnienia wspomnianej setnej rocznicy przybycia do francuskiej stolicy Fryderyka Chopina ${ }^{42}$. Bardzo obszerna, wydana w trzech tomach edycja korespondencji małżonków pozostaje niewątpliwie najcenniejszym źródłem do badań nad muzycznymi pasjami Anny i Jarosława Iwaszkiewiczów ${ }^{43}$.

Nie sposób objać jednym spojrzeniem wkładu Anny Iwaszkiewiczowej do dwudziestowiecznej refleksji na temat muzyki jej epoki. Jako wybitna erudytka, pisarka, tłumaczka literatury francuskiej, a nade wszystko wielka miłośniczka muzyki, pozostawiła bogatą spuściznę, która wciąż stanowi atrakcyjne wyzwanie dla humanistów spod znaku różnych dyscyplin. Rację miał przyjaciel rodziny Iwaszkiewiczów, poeta Paweł Hertz, doceniając jej osobowość jako „przypadek człowieka, który potrafi zachować proporcję między dziełem artystycznym i sprawami życia, gotów odwrócić się od codzienności ku rzeczywistości sztuki, widząc w niej skondensowane życie" 44 . A to właśnie muzyka była owego życia dominantą; jej rozwiązanie na tonikę wciąż wydaje się stanowić swego rodzaju drogowskaz do dalszych badań nad recepcją muzyki polskiej i światowej w Polsce I poł. XX stulecia.

\section{BIBLIOGRAFIA}

Anna i Jarostaw Iwaszkiewiczowie. Listy I922-I926. Red. Bożena Żyszkowska. Warszawa: Czytelnik, 1998.

Baranowski, Tomasz. Profile Skriabina. Szkice z poetyki twórczości. Białystok: Wydawnictwo Elan, 2013.

Chłanda, Dorota, Małgorzata Zawadzka. „O Szymanowskim z troską. Listy Anny i Jarosława Iwaszkiewiczów i Hélène Kahn-Caselli”. Polski Rocznik Muzykologiczny I8 (2020): 236-254.

Helman, Zofia. Między romantyzmem a Nowa Muzyka. Warszawa: Sutkowski Edition, 2013 (= Historia muzyki polskiej 6).

Hertz, Paweł. „W stronę Hani”. W: Paweł Herz. Gra tego świata, 277. Warszawa: Wydawnictwo Biblioteka „Więzi”, 1997.

Iwaszkiewiczowa, Anna. Dzienniki i wspomnienia. Warszawa: Czytelnik, 2012.

Matracka-Kościelny, Alicja. „Muzyka w życiu i twórczości Anny Iwaszkiewiczowej”. W: Anna Iwaszkiewiczowa. W setna rocznice urodzin, II5-I25. Podkowa Leśna: Muzeum im. A. i J. Iwaszkiewiczów w Stawisku, 1997 (= Stawisko. Almanach Iwaszkiewiczowski 3).

42 Zob. na ten temat: Radosław Romaniuk, Inne życie. Biografia Jarostawa Iwaszkiewicza, t. 1, Warszawa 2012, s. 405 i 434.

43 Mowa jest tu o pierwszej, lecz nie jedynej, edycji korespondencji Anny i Jarosława Iwaszkiewiczów, a mianowicie o trzech tomach w opracowaniu Małgorzaty Bojanowskiej i Ewy Cieślak, zawierających kolejno listy z lat: 1922-26 (Warszawa 1998), 1927-37 (Warszawa 2012) oraz 1932-39 (Warszawa 2014).

44 Paweł Hertz, W stronę Hani, w: tegoż, Gra tego świata, Warszawa 1997, s. 277. 
Matracka-Kościelny, Alicja. „Anna Iwaszkiewiczowa - Karol Szymanowski”. Polski Rocznik Muzykologiczny I8 (2020): 225-235.

Romaniuk, Radosław. „Anna od aniołów. O Annie Iwaszkiewiczowej”. W: Radosław Romaniuk. One. Kobiety, które kochaty pisarzy, 68-I24. Warszawa: Wilk\&Król Oficyna Wydawnicza, 20I4.

Romaniuk, Radosław. Inne życie. Biografia Jarostawa Iwaszkiewicza. T. I-2. Warszawa: Iskry, 20I2, 2017.

Włodek, Ludwika. Pra. Iwaszkiewiczowie. Opowieść o rodzinie. Kraków: Marginesy, 2012.

„Z Albumu Romana Jasińskiego. O Lilpopach, Hannie i Jarosławie Iwaszkiewiczach i trochę o sobie samym" [wywiad prasowy Roberta Jarockiego z Romanem Jasińskim]. Literatura I4, $\operatorname{nr} 5($ I985): 5-9.

\section{'ALL DAY LONG I AM ABSORBED BY SOME MUSICAL SENTENCE...' MUSIC AS ANNA IWASZKIEWICZ'S LIFELONG PASSION AND A LEITMOTIV OF HER WRITINGS}

Anna Iwaszkiewicz's diaries and memoirs contain many thoughts on music, which she listened to every day, as well as frequently playing piano, often four handed with Karol Szymanowski, her husband's cousin, with whom she maintained very warm relations. Her comments quoted in this article confirm her profound sensitivity to the music of great composers from the past, particularly Bach, Beethoven, Chopin and Wagner. There are also critical remarks, aimed mostly at the music of the so-called French impressionists, Debussy and Ravel.

Iwaszkiewicz also emerges from her diaries and memoirs as an expert on musical interpretation. Her private reviews of numerous concerts and operas contribute to the history of Warsaw's musical life during the first half of the twentieth century.

Translated by Tomasz Zymer

Słowa kluczowe / keywords: pamiętniki i wspomnienia / diaries and memoires, życie muzyczne w Warszawie / musical life in Warsaw, kultura muzyczna I poł. XX w. / musical culture in the first half of the 2oth century, Aleksander Skriabin / Alexander Scriabin, Karol Szymanowski, Jarosław Iwaszkiewicz

Dr hab. Tomasz Baranowski, muzykolog, pianista, nauczyciel akademicki, prelegent muzyczny. Autor dwóch książek: Estetyka ekspresjonizmu w muzyce XX wieku (2006, praca nominowana do Nagrody im. Jana Długosza) i Profile Skriabina. Szkice z poetyki twórczości (2013) oraz ponad 50 artykułów naukowych, poświęconych głównie zagadnieniom historii muzyki polskiej XIX i XX w. i estetyki muzyki epoki modernizmu. Wielokrotnie prezentował wyniki swoich badań podczas konferencji ogólnopolskich, a także na forum międzynarodowym, wykładając i wygłaszając referaty w Austrii, Niemczech, Francji, Belgii, Kanadzie i na Litwie. Jest adiunktem w Instytucie Muzykologii Uniwersytetu Warszawskiego.

tbaranowski@uw.edu.pl 